$10 \mid 2006$

Varia

\title{
Les opérations archéologiques 2005-2006
}

\section{(2) OpenEdition}

1 Journals

Édition électronique

URL : https://journals.openedition.org/cem/339

DOI : 10.4000/cem.339

ISSN : 1954-3093

Éditeur

Centre d'études médiévales Saint-Germain d'Auxerre

Édition imprimée

Date de publication : 15 août 2006

ISSN : 1623-5770

Référence électronique

"Les opérations archéologiques 2005-2006 », Bulletin du centre d'études médiévales d'Auxerre / BUCEMA [En ligne], 10 | 2006, mis en ligne le 15 juin 2006, consulté le 22 septembre 2022. URL : http:// journals.openedition.org/cem/339; DOI : https://doi.org/10.4000/cem.339

Ce document a été généré automatiquement le 22 septembre 2022.

\section{(c) (i) (2)(2)}

Creative Commons - Attribution - Pas d'Utilisation Commerciale - Partage dans les Mêmes Conditions 4.0 International - CC BY-NC-SA 4.0

https://creativecommons.org/licenses/by-nc-sa/4.0/ 


\section{Les opérations archéologiques 2005-2006}

1 Nous présentons dans cette section des résumés des travaux archéologiques menés par le Centre d'études médiévales. Ils concernent deux types d'opération. D'une part, celles réalisées dans le cadre des programmes de recherche définis au sein du conseil d'administration du CEM. D'autre part, depuis que le Centre a été habilité, des interventions préventives préconisées par la loi sur des sites menacés ou des monuments à restaurer, alors qu'ils présentent des problématiques intéressant les axes de recherche du CEM.

2 Parallèlement, nous invitons les autres chercheurs archéologues médiévistes, membres titulaires ou membres associés à l'UMR 5594, qui dans le cadre de l'INRAP ou d'autres instances, ont travaillé sur des sites du Moyen Âge ou sur des sujets en rapport avec les recherches développées par le CEM et l'UMR. 